\title{
Two new records of Gynandromorphs in Xylocopa (Hymenoptera, Apidae s.I.)
}

\author{
Rony Peterson Santos Almeida ${ }^{1,2}$; Luis Anderson Ribeiro Leite ${ }^{2,4}$ \& Kelli dos Santos Ramos ${ }^{3}$ \\ 1 Museu Paraense "Emílio Goeldi" (MPEG), Programa de Pós-Graduação em Zoologia (PPGZO0L), \\ Coordenação de Ciências da Terra e Ecologia (CCTE). Belém, PA, Brasil. ORCID: 0000-0003-0681-0357. E-mail: rony__peterson@hotmail.com \\ ${ }^{2}$ Universidade Federal de Sergipe (UFS), Centro de Ciências Biológicas e da Saúde (CCBS), Departamento de Biologia (DBI), \\ Laboratório de Entomologia (LABENTO). São Cristóvão, SE, Brasil. \\ 3 Universidade de São Paulo (USP), Museu de Zoologia (MZUSP). São Paulo, SP, Brasil. ORCID: 0000-0003-1453-5885. \\ E-mail: kellisramos@gmail.com \\ ${ }^{4}$ ORCID: 0000-0002-3702-4925. E-mail: landersonrleite@gmail.com
}

\begin{abstract}
Two new records of gynandromorphs in Xylocopa Latreille, 1802 (Hymenoptera, Apidae). Gynandromorphs are deviant morphological individuals with genetically distinct male and female tissues. Records of sex anomalies seems to be important to better understand the mechanisms regulating phenotypic expression. Herein, two new cases of gynandromorphs in carpenter bee species of Xylocopa from Brazil are described and figured: a mixed gynandromorph of the X. (Neoxylocopa) brasilianorum (Linnaeus, 1767) from São Paulo and a bilateral gynandromorph of the X. (Neoxylocopa) ordinaria Smith, 1874 from Sergipe.
\end{abstract}

Key-Words. Anomaly; Brazil; Carpenter bee; Morphology; Neoxylocopa.

\section{INTRODUCTION}

Intersexes and gynandromorphs are sexual anomaly frequently documented in bees (see Hinojosa-Díaz et al., 2012). Intersex individuals are genetically uniform although exhibits features of the opposite sex, while gynandromorphs (also called gynanders) are genetically chimeric individuals that display characteristics of both sexes simultaneously in the body (Michez et al., 2009; Narita et al., 2010). A precisely classification of the deviant phenotypes into intersexes or gynandromorphs is complicated, especially when the recognition is based only on the external morphologies (Narita et al., 2010, Ramos \& Ruz, 2013). According to Michez et al. (2009), gynandromorphs are classified into three mains forms: (i) bilateral, when the body is divided in left-right in relation to male and female features, (ii) transverse, is defined when sex characters are distributed in two asymmetrical parts, and (iii) mosaic or mixed, when display randomly female-male characters in different parts of the body. The mosaic class is the most common type of gynandromorphs described for bees (Wcislo et al., 2004; Lucia \& Gonzalez, 2013). The hypotheses to explain the causes of gynandromorphism among Apoidea have been related to problems of fertilization, polyspermy, loss or damage of a sex chromosome, and association with symbionts such as Wolbachia (see Michez et al., 2009 and Narita et al., 2010 for a thorough discussion).
Gynandromorphs are known to be rare in the nature and in addition to the lack of information, it is difficult to say how common this phenomenon is among bees. However, bees are sexually dimorphic which makes it easier to notice gynandromorphs compared to taxa that do not show remarkable number of secondary sexual characters. Gynander individuals in bees (Apidae s.l.) is known for approximately 138 species belonging to 35 genera in almost all subfamilies (Andreninae, Apinae, Halictinae, Colletinae, Megachilinae, Melittinae) (Sandhouse, 1923; Hicks, 1926; Urban, 1999; Gonzalez, 2004; Wcislo et al., 2004; Oliveira \& Andrade, 2006; Michez et al., 2009; Lucia et al., 2009; Sampson et al., 2010; Giangarelli \& Sofia, 2011; Fateryga et al., 2011; Hinojosa-Díaz et al., 2012; Lucia et al., 2012; Silveira et al., 2012; Camargo \& Gonçalves, 2013; Lucia \& Gonzalez, 2013; Alvarez et al., 2014; Lucia et al., 2015; Spring et al., 2015; Suzuki et al., 2015; Vivallo, 2015; Coelho et al., 2016; Zama \& Coelho, 2017). Most described of these gynandromorphs are recorded from the long-tongued bees in the genera Megachile and Xylocopa (Wcislo et al., 2004; Michez et al., 2009; Hinojosa-Díaz et al., 2012; Lucia et al., 2012).

In Xylocopa most of the documented gynanders are related to species in the Neotropical subgenus Neoxylocopa Michener (Hinojosa-Díaz et al., 2012; Lucia et al., 2012; Lucia \& Gonzalez, 2013). The subgenera is composed by large bees (about $20 \mathrm{~mm}$ ) widely distributed in the Americas 
that present a strong sexual dimorphism with black females and yellow or testaceous males (Hurd, 1978; Michener, 2007; Silveira et al., 2002; Marchi \& Alves-dosSantos, 2013). These differences of color among the sexes of $X$. (Neoxylocopa) is probably the easier observed character to diagnose gynandromorphs individuals. Currently, there are 18 listed cases of gynandromorphism in 13 different species of Xylocopa with 7 species of these reported for the subgenus Neoxylocopa: X. atamisquensis Lucia \& Abrahamovich, 2010, X. augusti Lepeletier, 1841, $X$. darwini Cockerell, 1926, X. frontalis (Olivier, 1789), X. mendozana Enderlein, 1913, X. nigrocincta Smith, 1854, $X$. varipuncta Patton, 1879 (Michez et al., 2009; Lucia \& Gonzalez, 2013; Lucia et al., 2015; Vivallo, 2015; Zama \& Coelho, 2017).

Descriptions of gynandromorphs can improve the understanding of this spectacular phenomenon and is a relevant data on the current knowledge to the evolution of mechanisms regulating phenotypic expression (Hinojosa-Díaz et al., 2012; Camargo \& Gonçalves, 2013). The study of gynandromorphic mutations help to reveal the developmental processes that facilitate the evolution of phenotypes (Yang \& Abouheif, 2011). These morphological deviations provide data for a general view that help in understanding the evolution of sexual characteristics or even homologies between male and female structures (Wcislo et al., 2004; Hinojosa-Díaz et al., 2012; Zama \& Coelho, 2017). Records of gynander specimens of bees are important in studies that focus on elucidating the mechanisms of sex determination and differentiation (Narita et al., 2010), to study the distribution of deviant phenotypes in tagma (between and within them for different taxa; see Hinojosa-Díaz et al., 2012 for a thorough discussion) and to explore these anomalies in the phylogenetic history of the group.

In this contribution we described and illustrate two new cases of gynandropmorphism in carpenter bee species of Xylocopa (Neoxylocopa) from Brazil: a mosaic gynandromorph of the $X$. (Neoxylocopa) brasilianorum (Linnaeus, 1767) from São Paulo state and a bilateral gynandromorph of the $X$. (Neoxylocopa) ordinaria Smith, 1874 from Sergipe state. There are two previous cases of gynander reported in the literature that have been attributed to the species names of $X$. brasilianorum and X. ordinaria. According to Lucia \& Gonzalez (2013) the correct name for the mosaic gynandromoph from Argentina described by Enderlein (1913) as X. ordinaria is actually a specimen of Xylocopa atamisquensis Lucia \& Abrahamovich, 2010 and the other Argentinean gynander described by Benoist \& Berland (1935) as X. brasilianorum might also be a specimen of $X$. atamisquensis, since that this species does not occur in Argentina. Therefore, the presented work is the first record of a gynandromorphic specimen for these two species.

\section{MATERIAL AND METHODS}

Gynandromorph descriptions are provided emphasizing the observed sexual features. The general morpho- logical terminology follows Michener (2007); metasomal terga and sterna are cited as T1-T7, and S1-S8, respectively. Genitalia structures were recognized with assistance of Packer (2003). All measurements are expressed in millimeters $(\mathrm{mm})$. With the purpose of comparison of the morphological variability, normal specimens were studied from the material deposited in the Museu de Zoologia, Universidade de São Paulo, São Paulo, Brazil (MZSP).

The specimens labels were transcribed with apostrophe marks (' ') indicating information of different labels attached to the same specimens and word between brackets ([ ]) to explicit abbreviated or important concealed information. The terminalia (genitalia and associated sterna) were detached from the metasoma, cleared in a $10 \% \mathrm{KOH}$ solution for $24 \mathrm{~h}$, neutralized in acetic acid, and stored in a vial with glycerin. The Figs. 1 and 3 were taken with a Canon EOS Rebel T3i camera with Canon MP-E, StackShot macro-rail and Griffi Equipamentos portable camera stand, using focus stacking performed by software Zerene Stacker. Figs. 2, 4-7 and 12-15 were obtained using a Leica video camera DFC 295 attached to a Leica stereomicroscope (M205C), and the series of images were combined in the software LEICA LAS (Leica Application Suite V3.6.0) or Combine ZP to produce confocal images. Images of adults of Xylocopa ordinaria (Figs. 8-11) were taken with a Sony DSC HX-300 camera. Final figures were edited in commercial software for small adjustments, such as brightness and contrast, and for highlight structures.

\section{RESULTS AND DISCUSSION}

\section{Xylocopa (Neoxylocopa) brasilianorum (Linnaeus, 1767) \\ Gynandromorph}

(Figs. 1-7)

\section{Examined material}

One gynandromorph specimen, labeled as follows '[Brazil], São Paulo, Jundiahy[Jundiaí], M. Beron leg., xi.[19]00' '1.932' '102.025' 'Xylocopa brasilianorum L., Hermaphrodito!, R.v. Ihg. det.'and'Xylocopabrasilianorum, 1293, Hermaphrodito!, M. Beron 17.ii.00 Jundiahy' deposited in the collection of the Hymenoptera Laboratory, Museu de Zoologia, Universidade de São Paulo (MZSP).

\section{Description}

Body length: $24.1 \mathrm{~mm}$; maximum head width: $7.0 \mathrm{~mm}$; right forewing length: $20.8 \mathrm{~mm}$; left forewing length: $20.7 \mathrm{~mm}$; maximum mesoscutum width: $10.5 \mathrm{~mm}$; maximum metasoma width: $11.0 \mathrm{~mm}$. This gynandromorph specimen is well defined as mosaic pattern. Female and male traits are distributed irregularly along the body.

Head: The head presents a mixed constitution of female and male. The right half of vertex, frons, paraocular area, 
supraclypeal area, clypeus, and labrum with female features and predominantly male in the left side; right antenna as female with 10 flagellomeres; left antenna is missing; mandibles and proboscidean structures male in the right side and female in the left side; genal area and occiput with male features in the right side and female on left half.

Mesosoma: Displaying a mosaic of male and female characters. The right half of pronotum and mesoscu- tum is male (except by the black pronotal lobe) and the left side is female. Mesepisternum and metepisternum as female. Scutellum and metanotum entirely male. Propodeum female on the right side and male on left side. The right forewing as male in which the second submarginal cell show the first and second $r-m$ veins strongly convergent (almost touching on upper side); the first and second $r-m$ veins of the left forewing is relatively less convergent, similar to female. The legs show a mixture of male and female characters. Right foreleg

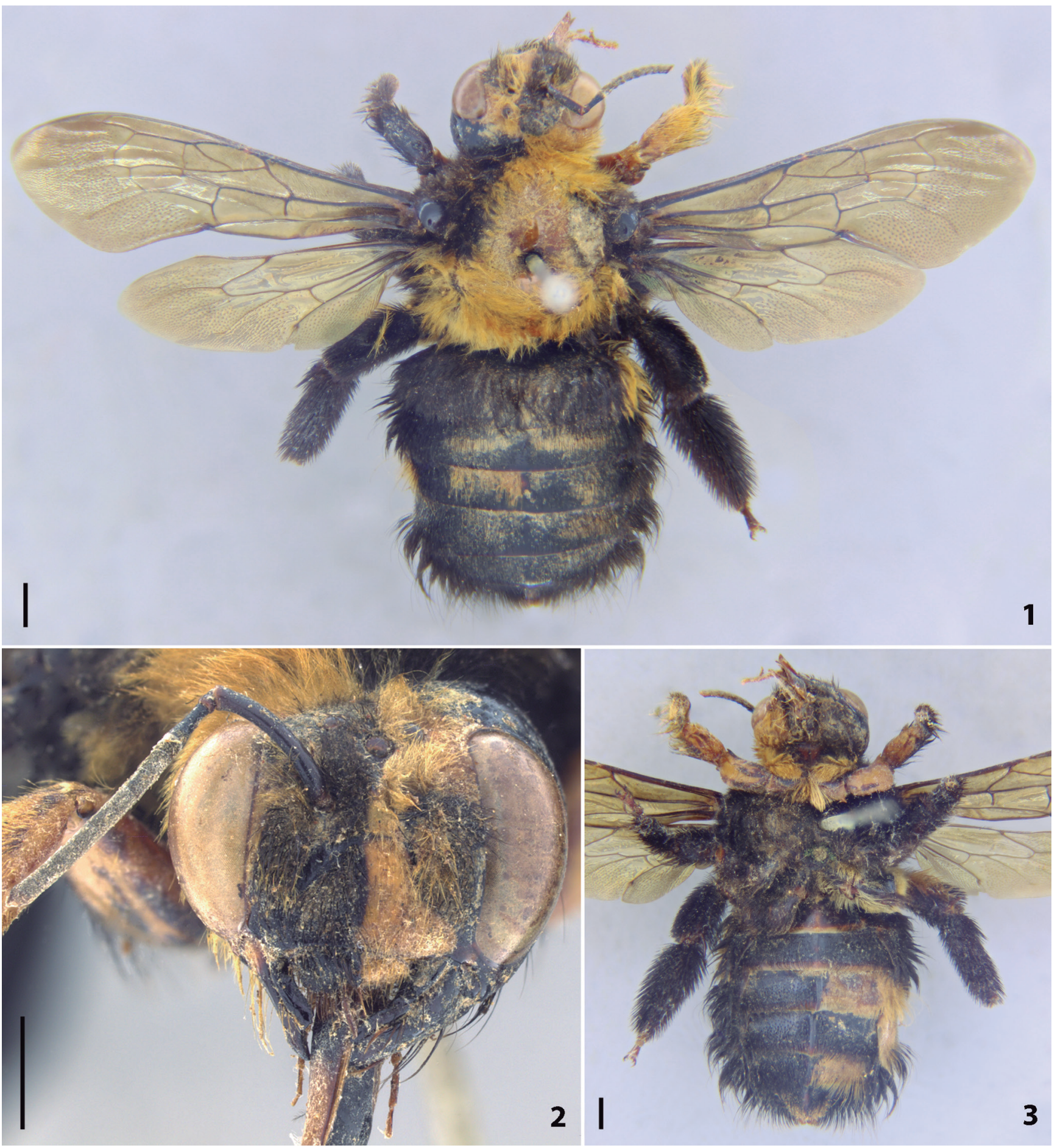

Figures 1-3. Gynandromorph of Xylocopa (Neoxylocopa) brasilianorum from Jundiaí, São Paulo (Brazil). (1) Habitus in dorsal view. (2) Head in frontal view. (3) Habitus in ventral view. Scale bars $=2 \mathrm{~mm}$. 

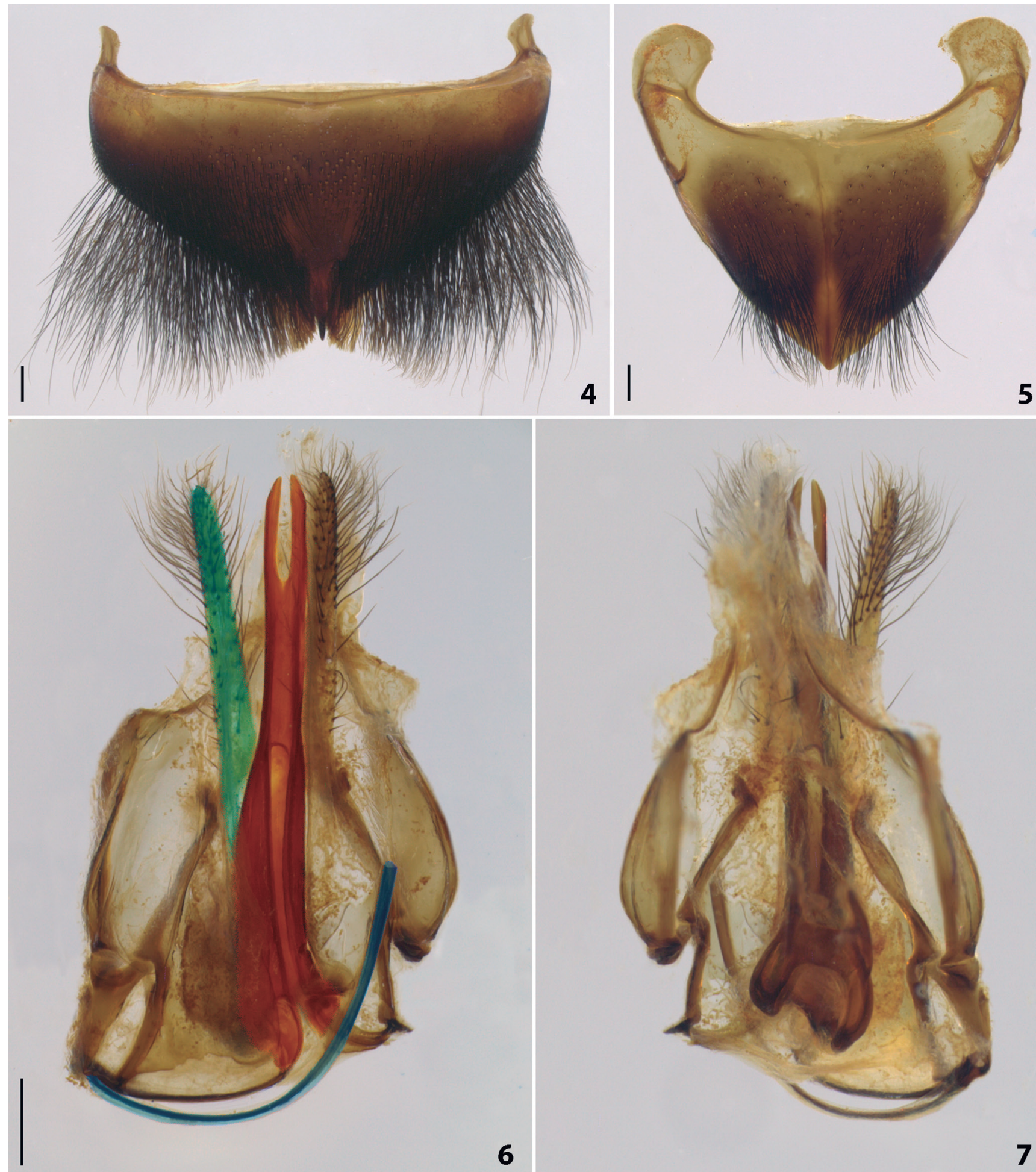

5

Figures 4-7. Gynandromorph of Xylocopa (Neoxylocopa) brasilianorum from Jundiaí, São Paulo (Brazil). (4) Tergum 6 in dorsal view. (5) Sternum 6 in ventral view. (6) Genitalia in ventral view. (7) Genitalia in dorsal view. Green: gonostylus, red: sting shaft, blue: lancet. Scale bars $=0.5 \mathrm{~mm}$.

entirely as male. Left foreleg mostly female with yellow integument and pubescence (male traits) on the coxa, trochanter, and underside portion of tibia; left femur of fore leg with rounded margin on posterior portion and yellow integument and pubescence underside as male. Mid legs as female. Hind legs predominantly female except by some yellow pubescence (male attribute) on the left coxa, trochanter, and posterior portion of femur and inner portion of tibia.
Metasoma: Predominantly female with some male areas, visible by yellow pilosity. Metasomal terga and sterna as female, with six exposed segments. Pigidial plate and fimbria on T6 as female (Figs. 4-5). Pubescence, punctuation, and color as female, except by yellow pilosity typical of male in the lateral of right side on T1 and T2, left side on T3 and T4, left half of S3 and S5 (Fig. 3). The genital structure as female with evident sting apparatus, slightly asymmetric; first valvifer 
(lancet), second valvifer (gonostylus), and sting shaft visible (Figs. 6-7).

\section{Xylocopa (Neoxylocopa) ordinaria Smith, 1874 Gynandromorph}

(Figs. 8-15)

\section{Examined material}

One gynandromorph specimen, labeled as follows 'Brasil, Sergipe, Itabaiana, Campus UFS, vii.2012, Almeida, R.P.S. leg' 'CEUFS 4300' 'Xylocopa cfr. ordinaria, GAR Melo 2014 det.' and deposited in the Laboratory of Entomology, Coleção Entomológica, Universidade Federal de Sergipe, Aracaju, Sergipe (CEUFS).

\section{Description}

Body length: $21.7 \mathrm{~mm}$; maximum head width: $7.0 \mathrm{~mm}$; right forewing length: $23.3 \mathrm{~mm}$; left forewing length: $21.3 \mathrm{~mm}$; maximum mesosoma width: $7.2 \mathrm{~mm}$; maximum metasoma width: $11.3 \mathrm{~mm}$. The gynandromorph presents a bilateral symmetry condition.

Head, mesosoma and metasoma: Body structures, integument, and pubescence on right side femalesand the left side male. Left antenna with 11 flagellomeres and the right with 10 flagellomeres. The sixth segment of metasoma has the appearance of female on the right side with a pygidial process (entirely suppressed on left side). The left side of the metasoma present an evident seventh terga, a typical structure of male, retracted beneath the T6 (Fig. 15). The condition of the genitalia and associated terga and sterna is complex, with anomalous and asymmetric morphology; both female (gonostylus, lancet, and hemitergite 7$)$ and male (T7, only a half portion) structures can be observed (Figs. 14-15).

\section{ACKNOWLEDGMENTS}

We are grateful to Dr. Eduardo José dos Reis Dias (Universidade Federal de Sergipe) for specimen donation of the gynander of Xylocopa ordinaria and to Gabriel Biffi who loaned the photographic equipment and helped with the photos of external morphology of X. brasilianorum. We also thanks to Dr. Gabriel Melo and Dr. Danuncia Urban (Universidade Federal do Paraná), and Dr. Paola Marchi (Universidade de São Paulo) for the identification of gynander specimens of Xylocopa ordinaria and X. brasilianorum, respectively. To the financial support provided by Conselho Nacional de Desenvolvimento Científico e Tecnológico - CNPq (KSR: 150409/2016-8 and RPSA: PCI-DC 313516/2015-4).
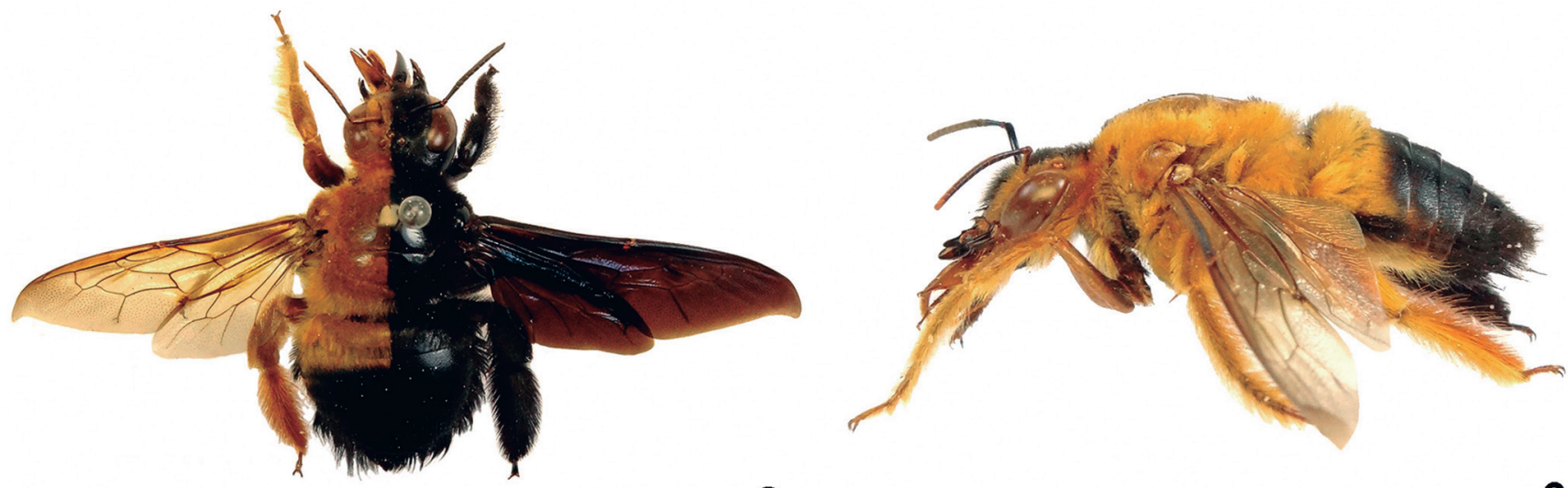

8
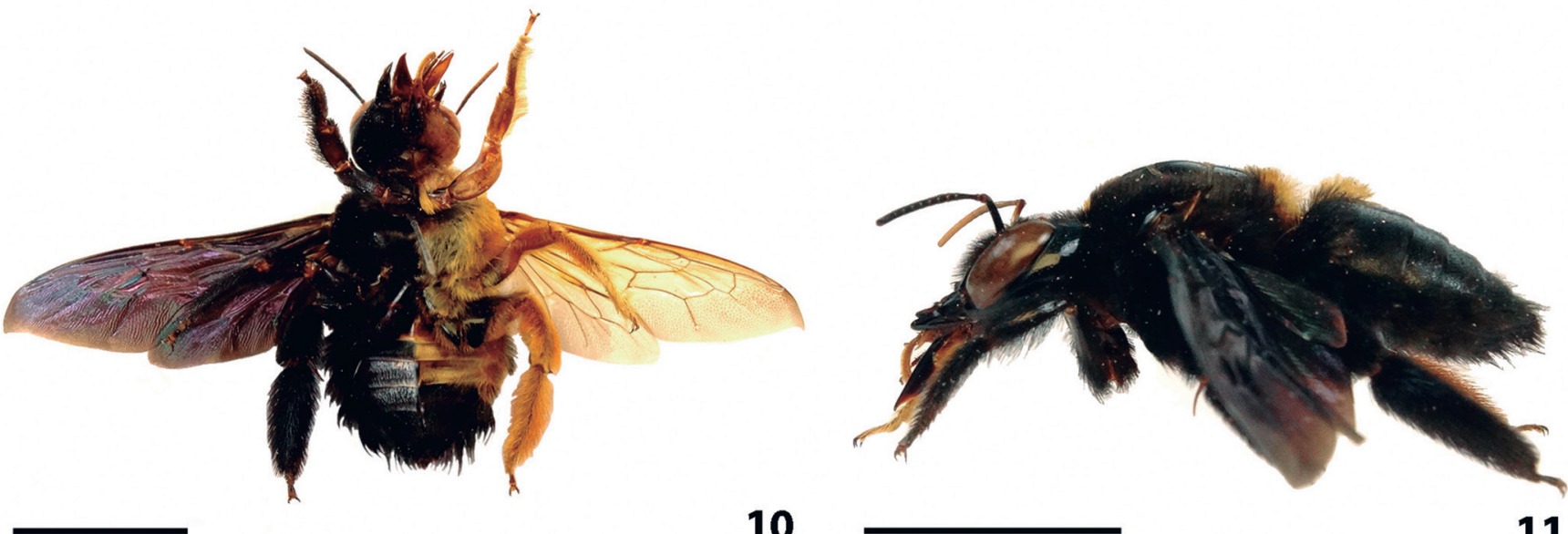

Figures 8-11. Gynandromorph of Xylocopa (Neoxylocopa) ordinaria from Itabaiana, Sergipe (Brazil). (8) Habitus in dorsal view. (9) Left side with male traits, in lateral view. (10) Habitus in ventral view. (11) Right side with female traits, in lateral view. Scale bars $=1 \mathrm{~cm}$. 

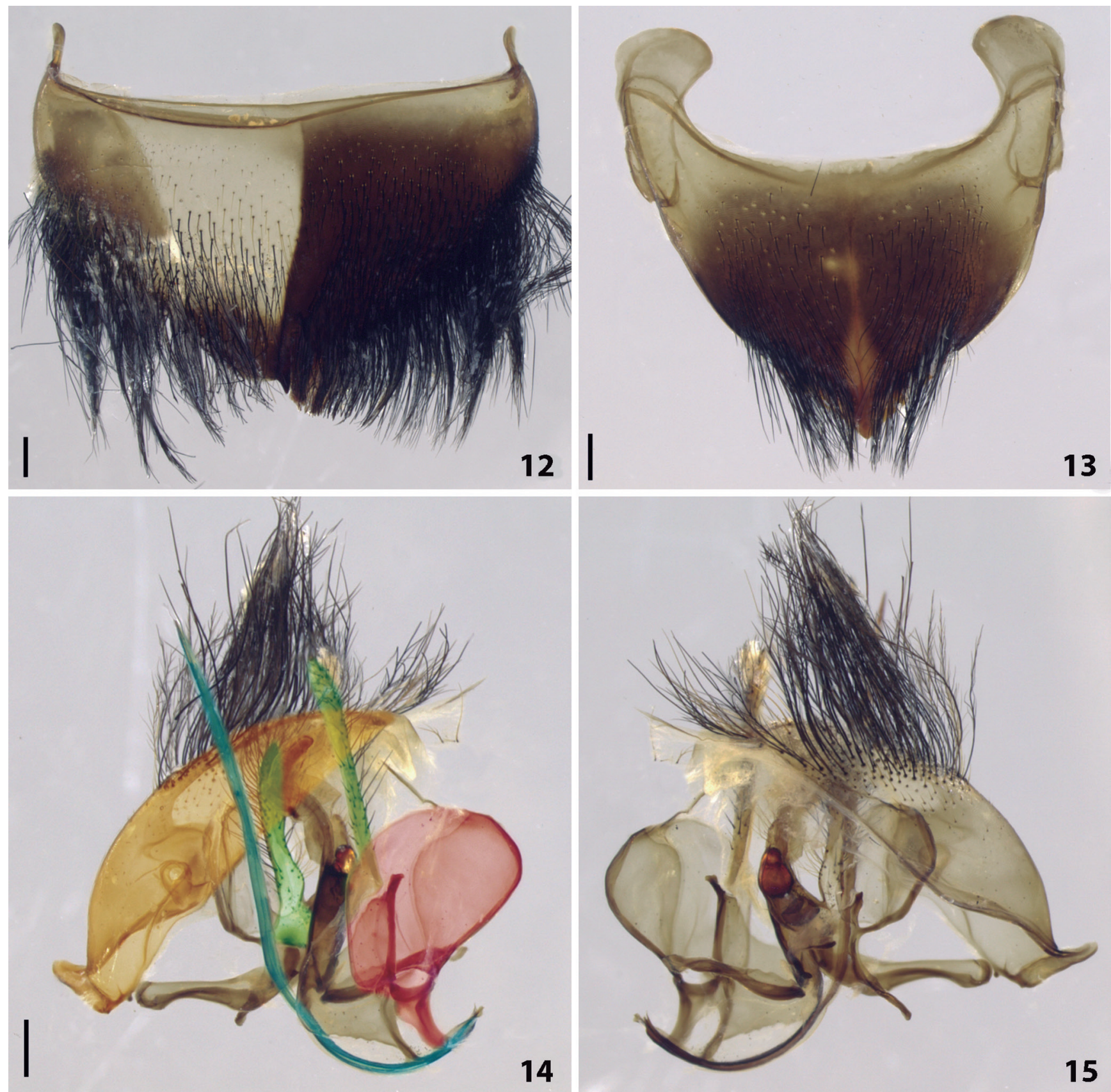

Figures 12-15. Gynandromorph of Xylocopa (Neoxylocopa) ordinaria from Itabaiana, Sergipe (Brazil). (12) Tergum 6 in dorsal view. (13) Sternum 6 in ventral view. (14) Genitalia in ventral view. (15) Genitalia in dorsal view. Green: gonostylus, orange: tergum 7 of male, red: hemitergite 7 of female, blue: lancet. Scale bars $=0.5 \mathrm{~mm}$.

\section{REFERENCES}

Alvarez, L.J.; Lucia, M.; Ramello, P.J. \& Abrahamovich, A.H. 2014. Description of two new cases of gynandromorphism in Paratrigona Schwarz and Augochlora Smith (Hymenoptera: Apidae and Halictidae). Zootaxa, 3889(3): 447-450. D0I

Benoist, R. \& Berland, L. 1935. Trois cas de gynandromorphisme chez lês hyménoptè res aculéates. Archives Museum History Natural Paris, 12: 435-438.

Camargo, M.P. \& Gonçalves, R.B. 2013. Register of a gynandromorph of Euglossa pleosticta Dressler (Hymenoptera, Apidae). Revista Brasileira de Entomologia, 57(4): 424-426. D0I

Coelho, I.R.; Zama, P.C. \& Ferrari, R.R. 2016. First record of gynandromorphism in Megachile (Pseudocentron) rubricata Smith, 1853 (Hymenoptera: Megachilidae). Pan-Pacific Entomologist, 92(2): 104-107. DOl
Enderlein, G. 1913. Ein hervorragender zwitter von Xylocopa mendozana aus Argentinien, mit einem Verzeichnis aller bisher beobachteten Gynandromorphen Hymenopteren. Stettiner Entomologische Zeitung, 74: 124-140. www.zobodat.at/pdf/Entomologische-ZeitungStettin 74 0124-0140.pdf.

Fateryga, A.V.; Ivanov, S.P. \& Filatov, M.A. 2011. Gynandromorphs of Megachile picicornis (Morawitz, 1877) and M. deceptoria (Pérez, 1890) (Hymenoptera: Megachilidae) and their evolutionary interpretation. Russian Entomological Journal, 20: 261-264.

Giangarelli, D.C. \& Sofia, S.H. 2011. First Record of a Gynandromorph Orchid Bee, Euglossa iopoecila (Hymenoptera: Apidae: Euglossini). Annals of the Entomological Society of America, 104(2): 229-232. DOI

Gonzalez, V.H. 2004. A gynandromorph of Megachile (Austromegachile) montezuma Cresson (Hymenoptera: Apoidea, Megachilidae). Entomotropica, 19(3): 155-156. www.bioline.org.br/pdf?em04025. 
Hicks, C.H. 1926. A gynandromorphic bee of the genus Dianthidium. American Naturalist, 60(667): 199-200. D0I

Hinojosa-Díaz, I.A.; Gonzalez, V.H.; Ayala, R.; Mérida, J.; Sagot, P. \& Engel, M.S. 2012. New orchid and leaf-cutter bee gynandromorphs, with an updated review (Hymenoptera, Apoidea). Zoosystematics and Evolution, 88(2): 205-214. DOI

Hurd, P.D. 1978. An Annotated Catalog of the Carpenter Bees (Genus Xylocopa Latreille) of the Western Hemisphere (Hymenoptera: Anthophoridae). Washington, Smithsonian Institution Press. 106p.

Lucia, M. \& González, V.H. 2013. A new gynandromorph of Xylocopa frontalis with a review of gynandromorphism in Xylocopa (Hymenoptera: Apidae: Xylocopini). Annals of the Entomological Society of America, 106(6): 853-856. DOI

Lucia, M.; Abrahamovich, A.H. \& Álvarez, L.J. 2009. A gynandromorph of Xylocopa nigrocincta Smith (Hymenoptera: Apidae). Neotropical Entomology, 38(1): 155-157. D0I

Lucia, M.; Álvarez, L. \& Abrahamovich, A.H. 2012. Gynandromorphism in Xylocopinae bees (Hymenoptera: Apidae): description of four new cases. Zootaxa, 3401: 37-42. DOI

Lucia, M.; Villamil, S.F. \& Gonzalez, V.H. 2015. A gynandromorph of Xylocopa augusti and an unusual record of $X$. iris from Brazil (Hymenoptera: Apidae: Xylocopini). Journal of Melittology, 53: 1-7. D0I

Marchi, P.\& Alves-dos-Santos, I. 2013. As abelhas do gênero Xylocopa Latreille (Xylocopini, Apidae) do Estado de São Paulo, Brasil. Biota Neotropica, 13(2): 249-269. DOI

Michener, C.D. 2007. The Bees of the world. Baltimore, The John Hopkins University Press. 992p.

Michez, D., Rasmont, P., Terzo, M. \& Vereecken, N.J. 2009. A synthesis of gynandromorphy among wild bees (Hymenoptera: Apoidea), with an annotated description of several new cases. Annales de la Société Entomologique de France, 45(3): 365-375. DOI

Narita, S.; Pereira, R.A.S.; Kjellberg, F. \& Kageyama, D. 2010. Gynandromorphs and intersexes: potential to understand the mechanism of sex determination in arthropods. Terrestrial Arthropod Reviews, 3(1): 63-96. DOI

Oliveira, F.F. \& Andrade, M.A.P. 2006. Ginandromorfia em Melipona mondury Smith (Hymenoptera, Apidae, Meliponinae). Sitientibus, 6: 272-276.

Packer, L. 2003. Comparative morphology of the skeletal parts of the sting apparatus of bees (Hymenoptera: Apoidea). Zoological Journal of the Linnean Society, 138: 1-38. D0I
Ramos, K.S. \& Ruz, L. 2013. First record of intersexual phenotype in Calliopsini bees (Hymenoptera, Apidae, Andreninae): an unusual specimen of Acamptopoeum submetallicum (Spinola). Zootaxa, 3609: 239-242. D01

Sampson, B.J.; Kirker, G.T. \& Werle, C.T. 2010. Morphology, courtship and mating of a mixed bilateral Gynander of Osmia ribifloris biedermannii Michener (Hymenoptera: Megachilidae). Journal of the Kansas Entomological Society, 83: 347-351. www.jstor.org/stable/40961684.

Sandhouse, G.A. 1923. A Gynandromorphic bee of the genus Osmia. American Naturalist, 57(653): 569-570. DOI

Silveira, F.A.; Melo, G.A.R. \& Almeida, E.A.B. 2002. Abelhas brasileiras. Sistemática e identificação. Belo Horizonte, Composição \& Arte. 252p.

Silveira, M.S.; Peixoto, M.H.P.; Martins, C.F. \& Zanella, F.C.V. 2012. Gynandromorphy in Eulaema atleticana Nemésio (Apidae, Euglossini). EntomoBrasilis, 5: 238-241.

Smith, F. 1874. Monograph of the genus Xylocopa, Latr. Transactions of the American Entomological Society, (1874): 247-307.

Spring, M.R.; Lustofin, K.S. \& Gardiner, M.M. 2015. Occurrence of a Gynandromorphic Bombus bimaculatus (Hymenoptera: Apidae) in Southeastern Ohio. The Great Lakes Entomologist, 48(3-4): 150-158.

Suzuki, K.M.; Giangarelli, D.C.; Ferreira, D.G.; Frantine-Silva, W.; Augusto, S.C. \& Sofia, S.H. 2015. A scientific note on an anomalous diploid individual of Euglossa melanotricha (Apidae, Euglossini) with both female and male phenotypes. Apidologie, 46(4): 495-498. DOI

Urban, D. 1999. Ginandromorfia em Alloscirtetica brethesi (Hymenoptera, Anthophoridae). Revista Brasileira de Zoologia, 16(1): 171-173. D0I

Vivallo, F. 2015. Novo registro de ginandromorfia em Xylocopa frontalis (Olivier, 1789) (Hymenoptera: Apidae: Xylocopini). In: Aguiar, A.J.C., Gonçalves, R.B., Ramos, K.S. (Orgs.). Ensaios Sobre as Abelhas da Região Neotropical: homenagem aos 80 anos de Danuncia Urban. Curitiba, Editora UFPR, pp. 293-299.

Yang, A.S. \& Abouheif, E. 2011. Gynandromorphs as indicators of modularity and evolvability in ants. Journal of Experimental Zoology, Part B, Molecular and Developmental Evolution, 316: 313-318. D0I

Zama, P.C. \& Coelho, I.R. 2017. New cases of gynandromorphism in Xylocopa Latreille, 1802 (Hymenoptera: Apidae). Papéis Avulsos de Zoologia, 57: 313-319. D0I

Wcislo, W.T.; Gonzalez, V.H. \& Arneson, L. 2004. A review of deviant phenotypes in bees in relation to brood parasitism, and a gynandromorphy of Megalopta genalis (Hymenoptera: Halictidae). Journal of Natural History, 38: 1443-1457. DOI 